\title{
Bullying: University Students Bring a Moral Perspective to Middle School Students
}

\author{
May A. Webber ${ }^{1}$ \\ ${ }^{1}$ Division of Humanities, St. John's University, New York, USA \\ Correspondence: May A. Webber, Division of Humanities, St. John's University, New York, USA. E-mail: \\ WEBBERM@stjohns.edu
}

Received: March 9, 2017

Accepted: March 30, 2017

Online Published: April 12, 2017

doi:10.5539/jel.v6n3p157

URL: http://doi.org/10.5539/jel.v6n3p157

"Philosophers have only interpreted the world in various ways; the point is to change it."

(Marx, 1848, "Theses on Feuerbach”)

\begin{abstract}
The prevalence of bullying and cyber-bullying in younger age groups has led to the inclusion of bullying in school-level curricula to address the seriousness of this issue and the prevention of these types of behavior. Higher education in its philosophy curricula can play a significant role in this regard as well. Proposed in this paper is an undergraduate ethics course Bullying and Moral Responsibility in which bullying is addressed from a moral perspective. This course has an academic-service learning component whereby this moral perspective is introduced to middle school students by university students. Peer learning of this sort might be of assistance in anti-bullying efforts.
\end{abstract}

Keywords: bullying, cyber-bullying, moral philosophy, ethics, academic service-learning, curriculum

\section{Introduction}

Like doctors without borders, bullying is an issue without borders; it extends well beyond being a schoolyard phenomenon. Today it permeates our work places and even our homes via the internet in the form of cyber-bullying (Note 1). Students should not be afraid to go to school; parents should not have to worry when sending their children off to school; employees should not be afraid to go to their places of work; no one should be in fear and trepidation of what should be the most secure of places: their homes. However, that is exactly the situation today for many individuals. Besides extending beyond the borders of the schoolyard bullying reaches well beyond our national borders; it is an international or global problem (Note 2).

The fact that bullying has driven individuals to what we would like to think is the unthinkable, namely, suicide is indicative of the seriousness of this issue and the urgency that it be vigorously addressed (Note 3).

Elementary and secondary schools have instituted curricula addressing bullying and cyber-bullying that either they or nonprofit organizations have created. In the United States, for instance, the Ophelia Project with its mission to create safer social climates provides lesson plans and other resources on internet safety toward realizing this goal (Note 4). The Anti-Defamation League's (ADL) national initiative, Cyberbullying: Understanding and Addressing Online Cruelty (Note 5) along with bullying prevention programs such as the Olweus Bullying Prevention Program (OBPP) (Note 6) are other such initiatives. Kindness, empathy and respect are often themes that are included in school curricula as ingredients to anti-bullying efforts. Second Step's Character Education Program, for example, purports to help "students know, care about, and act on core ethical values, such as fairness, honesty, compassion, responsibility, and respect for self and others" (Note 7). Recent research indicates that empathy does play a role in whether or not one engages in bullying behavior (Note 8).

However, at the college and university levels the same cannot be said. An examination of the literature revealed only scant inclusion of bullying and cyber-bullying in course curricula. This is even the case in the curricula of the discipline of philosophy where bullying could easily be addressed in ethics or moral philosophy courses. Yet unlike other issues such as abortion and world poverty (Note 9), bullying and cyber-bullying have received little 
if any attention at all when philosophers can contribute a valuable perspective to the issue of bullying, a moral perspective.

Toward this end, I have developed an undergraduate ethics course, Bullying and Moral Responsibility, specifically addressing bullying from a moral point of view. This paper introduces and explores this course attempting to demonstrate that higher education can indeed be a vehicle through which bullying and cyber-bullying can be substantially addressed thereby assisting in world-wide anti-bullying efforts. Before exploring Bullying and Moral Responsibility, let's take a look at the existing literature in this area.

\section{Literature Review}

A review of the literature revealed some inclusion of bullying in the curricula of college and university level courses. Although an early childhood education course offered by Highland Community College, Bullying Prevention and Response (Note 10) does focus on bullying, its concern is not with its ethical or moral dimension but rather with intervention and prevention strategies. Some courses offered by communication and computer science departments, such as Ethics in Communications (St. Joseph's University) (Note 11) and Exploring Digital Culture (Loyola University Maryland) (Note 12) include a discussion of bullying. These courses, however, have their weaknesses and limitations; they are not only not taught by those having an expertise in ethics, philosophers but, additionally, bullying is only one topic among a host of others addressed in the same course.

In our examination of the literature we did not find any philosophy course entirely devoted to bullying and/or cyber-bullying. Western University in Ontario, Canada offers a philosophy course, Digital Humanities (Note 13). Although taught by a philosopher, cyber-bullying is only one issue among numerous others addressed in the same course and it is treated only one week out of twelve weeks of topics. Additionally, the treatment of cyber-bullying was found to focus primarily on social media rules for teachers, as portrayed in the Centre for Digital Ethics and Policy's Social Media Rules for Teachers (Note 14) and in Smith and Yoon's a survey on the prevalence of cyberbullying in a Midwestern post-secondary institution (Note 15). It is not the ethical or moral perspective we are striving for in Bullying and Moral Responsibility. We also found that Plattsburgh State University of New York offers a philosophy course, Moral Problems, consisting of case studies for students to analyze; one case study was about soccer bullies (Note 16). The analysis focused on what one ought to do in a particular situation.

None of these courses offer a deep ethical or moral perspective to bullying and cyber-bullying. Bullying and Moral Responsibility does precisely this by virtue of being a course entirely focused on bullying and cyber-bullying from a moral point of view taught by moral experts, philosophers.

\section{Components to Bullying and Moral Responsibility}

There are basically three components to Bullying and Moral Responsibility. Let's refer to them as the academic, the service-learning, and the collaborative components.

The academic component is where philosophy students are introduced to the field of moral inquiry as they would be in any college or university ethics course (see Appendix I for a listing of the topics). Here they are provided with the tools, that is, the ethical or moral theories needed in order to evaluate bullying behavior from a moral point of view. What constitutes bullying and cyber-bullying is made abundantly clear. Bullying and cyber-bullying are then addressed in light of Aristotle's virtue ethics, Mill's utilitarianism, Kant's ethics of duty, and Rawls' veil of ignorance. Since Bullying and Moral Responsibility culminates with a presentation on the morality of bullying and cyber-bullying to middle school students, students enrolled in this course must work on bringing these theories down to a level that can be grasped by this middle school audience.

In sync with current trends in higher education, this course has an experiential part, an academic service-learning component providing students with the opportunity to address actively community or societal needs (Note 17). This component facilitates a transition from classroom to society; it enables students to integrate the learning that they have acquired in the classroom with meaningful community service and reflection. The community service aspect to Bullying and Moral Responsibility is a presentation on the morality of bullying and cyber-bullying to middle school students who have been invited to the university at the semester's end. Basically, the presentations focus around what moral philosophers would say about bullying behavior. Subsequent to the presentation, the philosophy students write reflection papers linking what they have learned in the academic service-learning project to what they have learned in the classroom. The academic service-learning component is intended to assist in the anti-bullying effort (Note 18). 
The collaborative component consists of philosophy students working with communication students in the creation of either videos, pamphlets, booklets, or posters that are used as education tools enhancing the presentation to the middle school students. The creation varies from semester to semester depending upon the communication course that is selected for collaboration with the philosophy students. The philosophy students are the directors providing the content for the producers, the communication students and the product they create.

\section{The Philosophical/Moral Perspective}

Prior to the 1970's bullying was not taken seriously by most disciplines; it was regarded as a harmless rite of passage, a normal part of growing up. Those bullied were told to toughen up, not to let it get the best of them, not to be so sensitive, and that it builds strength of character (Note 19). This thinking changed when Dan Olweus, the Swedish researcher and Professor of Psychology at the University of Bergen in Norway did an in-depth study of school bullying that delineated the detrimental effects on those afflicted (Note 20). Since, much research has been done on both short and long-term effects of bullying and cyber-bullying on the victim (Note 21) as well as the bully (Note 22). There is a growing body of evidence indicating that bullying in its digital form can be as detrimental as face-to-face bullying (Note 23).

The general consensus is that bullying must be taken seriously. It is unacceptable behavior; acts of bullying are unethical or immoral. Bullying and its $20^{\text {th }}$ century form, cyber-bullying, are indeed wrong and steps need to be taken to prevent it from occurring. Toward this end bullying prevention programs have been developed world-wide. There is a moral mandate that every effort be made to prevent bullying and cyber-bullying behavior.

Bullying and Moral Responsibility was developed to assist in this anti-bullying effort by approaching and exploring bullying and cyber-bullying from a moral point of view. It addresses the ethical question: Why is bullying and cyber-bullying wrong? In its academic service-learning component university philosophy students introduce middle school students to philosophers, their ethical theories and the application of the principles of these theories to bullying and cyber-bullying. Though moral dialogue with university students, middle school students come to see the rationale underlying the contention that bullying is wrong; they come to understand why bullying of any sort is said to be wrong.

\section{The Academic Component}

Aristotle's virtue ethics, Mill's utilitarianism, Kant's ethics of duty and Rawls' veil of ignorance can contribute to establishing this moral perspective on bullying and cyber-bullying that will be conveyed to middle school students (Note 24). Let's briefly explore each to see the role each can play.

Aristotle opens his Nicomachean Ethics stating that "every art and every inquiry, and similarly every action and pursuit, is thought to aim at some good, and for this reason the good has rightly been declared to be that at which all things aim" (Note 25). While most goods serve as means to other goods, there is this other good, the summum bonnum (the highest good) which is not a means to any other good; this Aristotle refers to as to as eudaimonia which translates as "happiness".

Aristotle is concerned with man's happiness or vital well-being. So, he asks: In what does man's happiness consist? What is the best kind of life for the human person? This he connects to our function or purpose. Just as a knife has a function, to cut, so too does man; our function has to do with the ratio (reason); our function is to reason, to reason to arête (excellence). When reason is applied to our daily life we find that our emotions, desires, appetites need to be regulated by some rational standard. This standard is the aurea mediocritus (the golden mean); not too much, not too little; avoid excess and deficiency; moderation in all things. It is not an arithmetic mean but rather it is a mean relative to the individual. Properly regulated emotions are considered to be virtues.

Ultimately, man's eudaimonia consists in continuous activity over a life time in accordance with virtue. A person of "good character" is a person who, through habituation, has been able to ingrain these virtues into his/her very being. Moral virtues are then, excellent traits of character which, importantly, dispose one to act in certain positive ways.

Introducing middle school students to Aristotle's ethics could involve asking them to make a list of traits of character that they consider to be virtues, drawing their attention to Aristotle's notion that a virtue is the mean lying somewhere between two extremes, and then, asking how they would go about incorporating these traits into their character. Concrete moral situations involving bullying could then be provided and students would be asked what role virtue ethics would play in resolving the situations. 
With no hesitation, Aristotle's ethics can be presented in terms with which middle school students can relate. Everyone wants to be happy; Aristotle in his Nicomachean Ethics tells us that in order to attain happiness you need to be a person of good character (Note 26). A person of good character displays gifts such as generosity, truthfulness, friendliness, kindness and compassion; these gifts are called virtues. Ultimately, by demonstrating good characteristics you will attain happiness. Being the best kind of person you can be will bring you happiness. Bullying brings out the worst in people; it displays negative qualities that cannot contribute to being a person of good character and so will not enable one to attain happiness. A person of good character would not bully.

The founder of utilitarianism, Jeremy Bentham, argued that there is only one ultimate principle, the principle of utility. As he stated in his Principles of Morals and Legislation: "By the Principle of Utility is meant that principle which approves or disapproves of every action whatsoever, according to the tendency which it appears to have to augment or diminish happiness of the party whose interest is in question, or what is the same thing in other words, to promote or to oppose that happiness" (Note 27).

Similarly, John Stuart Mill, utilitarianism's most eloquent spokesman, states that ... "The creed which accepts as the foundation of morals, Utility, or the Greatest Happiness Principle, holds that actions are right in proportion as they tend to promote happiness, wrong as they tend to produce the reverse of happiness. By happiness is intended pleasure and the absence of pain; by unhappiness, pain and the privation of pleasure" (Note 28). We are asked to seek the greatest happiness for the greatest number of people. In determining the moral status of an act, the utilitarian asks: Will this act produce greater overall human well-being than alternative acts?

To better understand utilitarianism as a moral theory, the middle school students could be asked to set up some very concrete scenario having to do with bullying/cyber-bullying in which they are faced with alternative courses of action from which it is difficult to choose. For each alternative action they would be instructed to list as best they can the projected consequences of each. They would also be asked to clarify who those persons are who would be affected in the given situation. Additionally, they must try to set up a way of measuring the happiness of those who would be affected by the alternative actions. Lastly, by reference to the quantified standard, they would be asked to decide which alternative would bring the most happiness to the greatest number of persons. A typical situation could focus on bystanders and the alternative courses of action that are open to them.

In sum, in accordance with utilitarian theory through our actions we should try to bring as much happiness into the world as possible; bullying does not do this. In fact, bullying brings more pain (unhappiness) into the world than happiness. There is the pain of the victim, the bystanders (those who witness the bullying), the family/friends of the victim and perhaps, ultimately, even the bully him/herself. It follows that bullying is immoral and cannot be condoned.

Immanuel Kant's ethics of duty breaks with utilitarianism in that rather than being a consequential theory where the morality of an act is determined by results, it is a deontological theory. For Kant the morality of an act is determined by intentions and reasons for acting; morality is a matter of following absolute rules that admit of no exceptions.

Kant poses a supreme principle of morality that he holds all rational beings must accept. This principle he calls the Categorical Imperative. In his work, Grounding for the Metaphysics of Morals, this principle is stated as: "Act only according to that maxim whereby you can at the same time will that it should become a universal law" (Note 29). In the same work, Kant gave another formulation of the same principle: "Act so that you treat humanity, whether in your own person, or that in another, always as an end and never as a means only" (Note $30)$.

This latter formulation demonstrates the high regard that he had for humanity. The human person he took to be this fabulous being distinct from all other beings having intrinsic worth or dignity by virtue of being rational and autonomous able to set their own goals and able to guide their lives by reason.

Middle school students would be asked to wrestle with one or both formulations of the Categorical Imperative to determine whether bullying/cyber-bullying would be morally permissible. With respect to the former formulation, students would be told to imagine that they are thinking about, for example, cyber-bullying a classmate. Next, they would be asked to formulate the maxim or rule that they would be following if they were to perform that act. Lastly, they would be asked whether they would be willing to allow everyone to follow the same rule at all times. If the answer is no, the act is immoral and they have a duty to refrain from performing it; it ought not to be done.

Whether bullying can be morally condoned via the latter formulation might be tackled by having students reflect on the act of bullying inquiring of them: If I were to bully/cyber-bully, would my act respect the ends or goals of 
others rather than merely using them for my own purposes? If the answer is no, I must not bully; bullying is immoral.

American philosopher, John Rawls, in his work, Theory of Justice, was searching for principles that would make a just society, a society in which justice conceived of as fairness prevails (Note 31). Toward this end, he poses a device, the veil of ignorance which when used will lead us to those principles.

Behind this veil of ignorance one pretends to know nothing about oneself; you know not what your position in society would be. In a slave-master society, for example, you do not know whether you would wind up a master or a slave; you might wind up a slave. So, you would not choose slavery as a societal institution. In a manner of speaking, behind this veil you are asked to walk in everyone else's shoes. More generally, this device may be used to determine the morality of an action or an institution.

Middle school students can easily understand this mechanism and apply it to the issue of bullying. The student would be asked to pretend not to know anything about himself/herself; he/she doesn't know whether he/she is black or white, gay or straight, rich or poor, smart or dumb, pretty or ugly, a nerd or a jock, fat or skinny, etc. All that is known is that he/she has the same basic needs and desires as everyone else. When considering the morality of bullying/cyber-bullying, the student would be asked to follow suit and pretend not to know whether he/she would wind up to be the bully or the victim. Students might be asked whether they would be willing to risk being the victim. Given the unlikeliness that they would, bullying would be said to be immoral.

\section{The Collaborative Component}

In the collaborative component to Bullying and Moral Responsibility the philosophy students collaborate with practicum students from the University's Division of Mass Communications on the creation of educational material that contributes to and enhances the presentation to middle school students. Videos, posters, booklets and pamphlets on bullying and cyber-bullying are examples of the educational material that students have created. The practicum class with which the philosophy students collaborate determines the nature of the product. Students might work alongside students enrolled in Corporate Video Design and Production to create a video or with those in Publication Graphics in producing posters or booklets that are used as an integral part of the presentations. The Bullying and Moral Responsibility students are the directors (i.e., they provide the content); the Corporate Video Design and Production and Publication Graphics students are the producers of the materials for the presentations.

\section{Sample Presentations}

Bullying and Moral Responsibility is now in its third year; it is offered in the fall semester each year. One semester the presentation rotated around a video titled: Do the Right Thing! It was created by philosophy students working alongside corporate video design and production students. During the course of the semester, the philosophy students studied ethical theory, bullying and cyber-bullying and applied the principles of the theories to bullying/cyber-bullying at a level that middle school students could comprehend creating the content for the video's script. Students from two courses Bullying and Moral Responsibility and Corporate Video Design and Production from very different university disciplines, philosophy and communications, worked closely together creating a video that served as a vehicle through which the presentation was delivered to middle school students. During the course of the semester, students in the Corporate Video Design and Production course went about their business of learning the skills of their trade: managing, producing and executing corporate video products so that toward the semester's end, they were ready and eager to apply their skills in "producing" the first video of their careers based on the script that the philosophy students had written. In addition to the technology employed in the video's creation, the students made use of digication thus making the video's script a part of their e-portfolios and they used portfolio village as the receptacle for the permanent storage of the video (Note 32).

In addition, public relations students under the direction of the philosophy students filmed some shots on the grounds of the campus and others in classrooms with the philosophy students as actors as they spoke all about bullying, acted out scenarios on bullying and discussed bullying from a moral perspective. They incorporated multiple still images of, for example, relevant philosophers and YouTube clips as well. In the aftermath, the middle school students wrote letters of thanks and reflection on the positive experience they had during their visit to the university.

Another presentation focused around the logo Buddies Not Bullies and employed the use of anti-bullying/cyber-bullying posters and a booklet titled Buddies Not Bullies the content of which included: definitions of bullying and cyber-bullying, descriptions of the various forms of bullying, activities (e.g., a word 
search), pertinent quotations from persons such as Dr. Martin Luther King, Jr., Eli Weisel, Soren Kierkegaard, and, most importantly, a section titled "What Philosophers Have to Say About Bullying", specifically Aristotle, Immanuel Kant, John Stuart Mill, and John Rawls. This moral perspective on bullying and cyber-bullying was reinforced through a lively interactive exchange with the sixth-graders during the presentation employing power-point, slides, video-clips and live skits rotating around scenarios on bullying and cyber-bullying, and a student-focused activity during which each student created his/her own anti-bullying poster, fastened it to the sides of a science board the center of which contained the logo, Buddies Not Bullies, and signed their name around the logo while taking an anti-bullying pledge.

\section{Course Evaluation}

In sync with Marx's notion that the philosopher's job is not only to interpret the world but also to change it, this course was developed to assist in the word-wide effort to combat bullying and cyber-bullying. The logo of the most recent presentation was Stop Bullying: Be the Change. Has Bullying and Moral Responsibility been effective in this regard? The philosophy student's reflection papers, conversations that the university students had with their middle school peers during the presentation, input contained in the letters of thanks received from the middle school students following the presentation, and the eagerness on part of the middle school teachers and administration to have their students continue attending these presentations every year indicate that a positive impact has been made (Note 33).

Some of the middle school students as well as the university students said that they were unaware that they were bullies. One university student wrote:

When we were done presenting, and I walked around to the different tables, a young girl looked at me and thanked me, saying "you know, I think this workshop really changed me. I was the bully and I didn't even know it". Knowing now that I helped to change that little girl's life, just one person, was one of the most rewarding feelings I have ever had, and I am forever grateful that I decided to take the Ethics of bullying/moral beliefs class (Note 34).

Another university student reflected that he had a history of being a bully and that "the course made him reflect and realize his shortcomings and even drove him to work on them and apologize to those he had hurt in the past" (Note 35). Similarly, in his note to us a middle school student wrote, "You guys are very convincing because I used to be a bully a little and I am not proud of it. But I am glad you stopped me before somebody got hurt really badly" (Note 36). Another wrote, "You guys are awesome! ... I think your anti-bullying project really helped me because my friends haven't teased me for the whole day! I really owe you guys for that" (Note 37)!

A number of the university students reflected that they would never forget the looks on the middle school students faces during the presentation. One in particular said that he "would never forget the look on some of the students faces, especially one little boy who sat all the way in the corner. He had this look that "someone finally understands my struggle'. It was almost a look of relief just to talk about it" (Note 38).

"We learned so much about how bullying is wrong and needs to be stopped" (Note 39); "You guys have really showed me a lot that bullying is not right... I really thank you because you are people I should look up to" (Note 40 ); "I just wanted to thank you for changing our lives and helping us understand that bullying is not a good" (Note 41). These are just a few additional comments made by the middle school students.

Bullying and Moral Responsibility we believe can be a vehicle of change. The inclusion of this course or courses similar in nature into university philosophy curricula can assist in the global anti-bullying effort. The moral perspective on bullying and cyber-bullying gets to the very foundation of bullying prevention initiatives by providing the rationale that can enable students to understand why bullying and cyber-bullying are wrong.

Middle school students clearly came to an understanding of the rationale or moral perspective underlying why bullying and cyber-bullying are wrong. At least in the short term there is evidence that Bullying and Moral Responsibility has contributed to the anti-bullying initiative. We can only hope that at least with respect to some students it has contributed long-term.

\section{Conclusion}

The general consensus today is that bullying and cyber-bullying are unacceptable behaviors, and commensurate with this belief is that they must be addressed with vigor. Curricula development can be an effective tool in bullying and cyber-bulling prevention. Included in the curriculum of elementary and secondary schools are initiatives and programs designed with this end in mind. 
This has not been so in higher education. In part, this is because it has not been addressed as a moral issue when this is usually the purview of academics dealing with philosophical matters.

Our attempt with this discussion of a university course on bullying and cyber-bullying, Bullying and Moral Responsibility, has been to demonstrate how curriculum in a university philosophy course can achieve a new dialogue and perspective on bullying. Philosophers are moral experts and as such have a valuable perspective to contribute on the issues of bullying and cyber-bullying, a moral or ethical perspective. In its academic service-learning component this course reaches out to middle school students conveying to them the rationale underlying the wrongness of bullying behavior thereby enriching, expanding and contributing to the universal knowledge of bullying.

Feedback from university and middle school students, teachers and administrators support the contention that this course has had some degree of success assisting in the anti-bullying effort at least in the short-term. Some measures, however, are needed to determine its long-term success. It is hoped that Bullying and Moral Responsibility will serve as an incentive to other academics in philosophy and other college and university disciplines to develop curricula designed to assist in bullying and cyber-bullying prevention.

\section{References}

Anscombe, G. E. M. (1958). Modern Moral Philosophy. Philosophy, 33, 124. https://doi.org/10.1017/S0031819100037943

Anti-Defamation League. (2008). Cyberbullying: Understanding \& Addressing Online Cruelty. Retrieved from http://www.adl.org

Balakrishnan, V. (2015). Cyberbullying among Young Adults in Malaysia: The Roles of Gender, Age and Internet Frequency. Computers in Human Behavior, 46, 149-157. https://doi.org/10.1016/j.chb.2015.01.021

Bentham, J. (1962). Principles of Morals and Legislation. In J. Bowring (Ed.), The Works of Jeremy Bentham. London, Reprinted New York.

Centre for Digital Ethics and Policy. (2013). Social media rules for teachers. Retrieved from http://digitalethics.org/essays/social-media-rules-for-teachers

Dempsey, A. G., Michael, L. S., Jack, D., \& Eric, A. S. (2009). Has Cyber Technology Produced a New Group of Peer Aggressors? Cyberpsychology, Behavior, and Social Networking, 14(5), 297-302. https://doi.org/10.1089/cyber.2010.0108

Garaigordobil, M. (2015). Cyberbullying in Adolescents and Youth in the Basque Country: Prevalence of Cybervictims, Cyberaggressors, and Cyberobservers. Journal of Youth Studies, 18, 569-582. https://doi.org/10.1080/13676261.2014.992324

Gini, G., \& Dorothy, L. E. (2014). Peer Victimization, Cyberbullying, and Suicide Risk in Children and Adolescents. Journal of the American Medical Association, 312(5), 545-546. https://doi.org/10.1001/jama.2014.3212

Groundwork of the Metaphysics of Morals. (1993). J. W. Ellington Trans (Original work published in 1785). Indianapolis: Hackett Publishing Company.

Hébert, A., \& Hauf, P. (2015). Student Learning through Service Learning: Effects on Academic Development, Civic Responsibility, Interpersonal Skills and Practical Skills. Active Learning in Higher Education, 16(1), 37-49. https://doi.org/10.1177/1469787415573357

Heiman, T., \& Olenik-Shemesh, D. (2015). Cyberbullying Experience and Gender Differences among Adolescents in Different Educational Settings. Journal of Learning Disabilities, 48(2), 146-155. https://doi.org/10.1177/0022219413492855

Highland Community College. (2014). Early childhood. Retrieved from https://highlandcc.edu/pages/early-childhood_0

Hinduja, S., \& Justin, W. P. (2008). Bullying Beyond the Schoolyard: Preventing and Responding to Cyberbullying. Thousand Oaks, CA: Corwin Press.

Kant, I. (1949). Foundations of the Metaphysics of Morals 1775. In L. W. Beck (Trans.), The Critique of Practical Reason and Other Writings in Moral Philosophy. Chicago: University of Chicago Press. 
Lies, J. M., Bock, T., Brandenberger, J., \& Trozzolo, T. A. (2012). The Effects of Off-campus Service Learning on the Moral Reasoning of College Students. Journal of Moral Education, 41, 189-199. https://doi.org/10.1080/03057240.2012.669925

Loyola University Maryland. (2014). Exploring Digital Culture. Retrieved from http://www.loyola.edu/academic/emergingmedia/curriculum/coursedescription

MacIntyre, A. (1984). After Virtue: A Study in Moral Theory. Notre Dame, Ind.: University of Notre Dame Press.

Marcoux, E. (2014). Cyberbullying and Technology. Teacher Librarian, 42, 69-70.

Marx, K. (1983). Thesis on Feuerbach. In Kamenka (Ed.), The Portable Karl Marx. New York: Penguin Books.

Mill, J. S. (1883). Utilitarianism. London: Parker, Son, and Bourn, West Strand.

Mitsopoulou, E., \& Theodoros, G. (2015). Personality Traits, Empathy and Bullying Behavior: A Meta-analytic Approach. Aggression and Violent Behavior, 216, 1-72. https://doi.org/10.1016/j.avb.2015.01.007

Noorden, T. J., Gerbert, T. H., Antonius, N. C., \& William, M. B. (2015). Empathy and Involvement in Bullying in Children and Adolescents: A Systematic Review. Journal of Youth and Adolescence, 44, 637-657. https://doi.org/10.1007/s10964-014-0135-6

Olweus, D, Swan, L., \& Sharon, F. M. (1999a). Bullying Prevention Program. Boulder, CO: Center for the Study and Prevention of Violence.

Olweus, D, Swan, L., \& Sharon, F. M. (1999b). Bullying Prevention Program: Blueprints for Violence Prevention, Book Nine. Boulder, CO: Center for the Study and Prevention of Violence, Institute of Behavioral Science, University of Colorado.

Olweus, D. (1978). Aggression in the Schools: Bullies and Whipping Boys. New York: Wiley.

Ophelia Project. About the Ophelia Project. (2010). Retrieved from http://www.opheliaproject.org

Ortega, R., Elipe, P., Mora-Merchan, J. A., Genta, M. L., Bright, A., Guarini, A., ... Tippett, N. (2012). The Emotional Impact of Bullying and Cyberbullying on Victims: A European Cross-national Sudy. Aggressive Behavior, 38, 342-356. https://doi.org/10.1002/ab.21440

Patchin, J., \& Sameer, H. (2006). Bullies Move Beyond the Schoolyard: A Preliminary Look at Cyberbullying. Youth Violence and Juvenile Justice, 4, 148-169. https://doi.org/10.1177/1541204006286288

Plattsburgh State University of New York. (2009). Moral Problems. Retrieved from http://www.plattsburgh.edu/academics/philosophy/moralproblems.php

Rawls, J. (1999). A Theory of Justice. Cambridge: Harvard University Press.

Rigby, K. (2003). Consequences of Bullying in Schools. Canadian Journal of Psychiatry, 48, 583-590. https://doi.org/10.1177/070674370304800904

Saint Joseph's University. (2014). Ethics in Communications. Retrieved from http://www.sju.edu/int/academics/cas/commstudies/curdesc.html

Seale, D., \& Gary, Y. (2003). Bullying and Victimization: Prevalence and Relationship to Gender, Grade Level, Ethnicity, Self-Esteem and Depression. Adolescence, 38, 152.

Second Step Program. (2014). Character Education and the Second Step Program (para. 1). Retrieved from http://www.cfchildren.org/second-step/research/character-education

Singer, P. (1972). Famine, Affluence and Morality. In Philosophy and Public Affairs. Animal Liberation, New York: Harper Collins Publisher, Inc.

Smith, J. A., \& Jiyoon, Y. (2013). Cyberbullying Presence, Extent and Forms in a Midwestern Post-secondary Institution. Information Systems Education Journal, 11, 52-78.

Snakenborg, J., Richard, V. A., \& Robert, A. G. (2011). Cyberbullying: Prevention and Intervention to Protect our Children and Youth. Preventing School Failure, 55, 88-95. https://doi.org/10.1080/1045988X.2011.539454

Thomas, H. J., Jason, P., Connor, J. P., \& James, G. S. (2015). Integrating Traditional Bullying and Cyberbullying: Challenges of Definition and Measurement in Adolescents-A Review. Educational Psychology Review, 27, 135-152. https://doi.org/10.1007/s10648-014-9261-7 
Thomson, A. M., Antoinette, S.-T., Anthony, V. N., \& Robert, G. B. (2011). Service Learning and Community Engagement: A Comparison of Three National Contexts. Voluntas: International Journal of Voluntary \& Nonprofit Organizations, 22, 214-237. https://doi.org/10.1007/s11266-010-9133-9

Van Geel, M., Paul, V., \& Jenny, T. (2014). Relationship between Peer Victimization, Cyberbullying, and Suicide in Children and Adolescents: A Meta-analysis. JAMA Pediatrics, 168, 435-442. https://doi.org/10.1001/jamapediatrics.2013.4143

Waasdorp, T. E., \& Catherine, P. B. (2015). The Overlap between Cyberbullying and Traditional Bullying. Journal of Adolescent Health, 56, 483-488. https://doi.org/10.1016/j.jadohealth.2014.12.002

Webber, M. A. (2014). Bullying and Moral Responsibility. In S. Inal, \& M. A. Webber (Eds.), From Communication Landscapes to Bullying Battlegrounds. Oxford, UK, Inter-Disciplinary Press. Retrieved from http://www.interdisciplinarypreee.net/online-store/ebooks/ethos-and-modern-life/from-communication -landscapes-tgo-bullying-backgounds

Western University. (2014). Digital Humanities. Retrieved from http://www.uwo.ca/arts/digitalhumanities/

Willard, N. (2006). Cyber Bullying and Cyberthreats: Responding to the Challenge of Online Social Cruelty, Threats and Distress. Eugene, OR: Center for Safe and Responsible Internet Use.

Wong-Lo, M., \& Lynda, M. B. (2011). Digital Agression: Cyberworld Meets School Bullies. Preventing School Failure, 55, 64-70. https://doi.org/10.1080/1045988X.2011.539429

Yan, J. (2008). Social Technology as a New Medium in the Classroom. New England Journal of Higher Education, 22, 27-30.

Ybarra, M. L., \& Kimberely, J. M. (2004). Online Aggressor/targets, Aggressors, and Targets: A Comparison of Associated Youth Characteristics. Journal of Child Psychology and Psychiatry, 45, 1308-1316. https://doi.org/10.1111/j.1469-7610.2004.00328.x

\section{Notes}

Note 1 . This $21^{\text {st }}$ century form of bully and the treat is poses is explored by Sameer Hinduja and Justin W. Patchin in Bullying Beyond the Schoolyard: Preventing and Responding to Cyberbullying (Thousand Oaks, CA: Corwin Press, 2008) and by Hannah J. Thomas, Jason P. Connor and James G. Scott, "Integrating Traditional Bullying and Cyberbullying: Challenges of Definition and Measurement in Adolescents-A Review", Educational Psychology Review, 27, 135-152.

Note 2. Its global nature is addressed in V. Balakrishnan, "Cyberbullying Among Young Adults in Malaysia: The Roles of Gender, Age and Internet Frequency", Computers in Human Behavior, 46, 149-157; Maite Garaigordobil, "Cyberbullying in Adolescents and Youth in Basque Country: Prevalence of Cybervictims, Cyberaggressors, and Cyberobservers", Journal of Youth Studies, 18, 569-582; T. Heiman and Dorit Olenik-Shemesh, "Cyberbullying Experience and Gender Differences Among Adolescents in Different Educational Settings", Journal of Learning Disabilities, 48, 146-155; World Health Organization [WHO]. (2013).

Note 3. The link to suicide is explored in Gianluca Gini and Dorothy L. Espelage, "Peer Victimization, Cyberbullying, and Suicide Risk in Children and Adolescents", Journal of the American Medical Association, 312, 545-546. For a meta-analysis see Mitch Van Geel, Paul Vedder and Jenny Tanilon, "Relationship between Peer Victimization, Cyberbullying, and Suicide in Children and Adolescents", Pediatrics, 168, 435-442.

Note 4. Ophelia Project. (2010). http://www.opheliaproject,org

Note 5. Anti-Defamation League Cyberbullying: Understanding and Addressing Online Cruelty. (2008). http://www.adl.org

Note 6. Dan Olweus, Susan P. Limber and Sharon F. Mihalic Bullying Prevention Program (Boulder, CO: University of Colorado: Center for the Study and Prevention of Violence, 1999a).

-----, Bullying Prevention Program: Blueprints for Violence Prevention. Book Nine (Boulder, CO: University of Colorado: Center for the Study and Prevention of Violence, Institute of Behavioral Science, 1999b).

Note 7. Second Step Program, Character Education and the Second Step Program. (2014). para.1. http://www.cfchildren.org/second-step/research/character-educatiion 
Note 8. Effrosyni Mitsopoulou and Theodoros Giovazolias, "Personality Traits, Empathy and Bullying Behavior: A Meta-analytic Approach", Aggression and Violent Behavior, 216, 1-72; Tirza J. Noorden et al., "Empathy and Involvement in Bullying in Children and Adolescents: A Systematic Review", Journal of Youth and Adolescents, 44, 637-657.

Note 9. See Peter Singer's Animal Liberation (New York: New York Book Review Books, 1975). Animal welfare was made a serious topic for discussion by contemporary philosophers. Also see "Famine, Affluence, and Morality", Philosophy and Public Affairs, 1(1), 229-243.

Note 10. Highland Community College, ECH 109 Bullying Prevention and Response. (2014). https://www.highlandcc.edu/pages/early-childhood0

Note 11. Saint Joseph's University. (2014). Ethics in Communications. November 22, 2014. http://www.sju.edu/int/academics/cas/commstudies/curdesc.html

Note 12. Loyola University Maryland. (2014). Exploring Digital Culture (2014). ME 601.W01. http://www.loyola.edu/academic/emergingmedia/curriculum/coursedescription1999):118

Note 13. Western University, Digital Humanities. (2014).

Note 14. Centre for Digital Ethics and Policy, Social Media Rules for Teachers (2013). http://digitalethics.org/essays/social-media-rulkes-for-teachers

Note 15. Julie A. Smith and Jiyoon Yoon, "Cyberbullying Presence, Extent and Forms in a Midwestern Post-secondary Institution", Information Systems Education Journal, 11(3), 52-78.

Note 16. Plattsburgh State University of New York, PHI 104 Moral Problems. (2009). http://www.plattsburgh.edu/academics/philosophy/moralproblems.php

Note 17. For the importance of an academic service component see: Ali Herbert and Petra Hauf, "Student Learning Through Service Learning: Effects on Acadmic Development, Civic Responsibility, Interpersonal Skills and Practical Skills", Academic Learning in Higher Education, 48, 37-49; James M. Lies et al., "The Effects of off-campus Service Leaning on the Moral Reasoning of College Students", Journal of Moral Education, 41, 189-199; Ann Marie Thomson et al., "Service Learning and Community Engagement: A Comparison of Three National Contexts", Voluntas: International Journal of Voluntary and Nonprofit Organizations, 22, 214-237.

Note 18. Academic Service-Learning is a high-impact practice at St. John's University. 93\% of St. John's first year students indicated that some or all courses that they took had the component of service learning, and this percentage is significantly higher than the $55 \%$ of Carnegie peers or the $60 \%$ of Catholic peers. $86 \%$ of St. John's seniors indicated that they had a service learning component in some or all of their courses. This percentage is significantly higher than $64 \%$ of Carnegie peers or the $73 \%$ of Catholic peers.

Note 19. Hyojin Koo, "A Time Line of the Evolution of School Bullying in Different Social Contexts", Asia Pacific Educational Review, 8(1), 107-116.

Note 20. Dan Olweus, Aggression in the Schools: Bullies and Whipping Boys (New Jersey: John Wiley \& Sons, Inc., 1978).

Note 21. See, for example, Rosario Ortega et al., "The Emotional Impact of Bullying and Cyberbullying on Victims: A European Cross-national Study", Aggressive Behavior, 38, 342-356; Kenneth Rigby, "Consequences of Bullying in Schools", Canadian Journal of Psychiatry, 48, 583-590; Dorothy Seals and Jerry Young, "Bullying and Victimization: Prevalence and Relationship to Gender, Grade Level, Ethnicity, Self-Esteem and Depression", Adolescence, 38(152); Michele L. Ybarra and Kimberly J. Mitchell, "On line Aggressor/Targets, Aggressors and Targets: A Comparison of Associated Youth Characteristics", Journal of Child Psychology and Psychiatry, 45, 1308-1316; Nancy N. Willard, Cyber Bullying and Cyber Threats: Responding to the Challenge of Online Social Cruelty, Threats and Distress (Eugene, Oregon: Center for Safe and Responsible Internet Use, 2006).

Note 22. Allison G. Dempsey et al., "Has Cyber Technology Produced a New Group of Peer Aggressors?", Cyberpsychology, Behavior, and Social Networking, 14(5), 297-302.

Note 23. Mickie Wong-Lo and Lynda M. Bulloock, "Digital Aggression: Cyberworld Meets School Bullies", Preventing School Failure, 55(2), 64-70.

Justin Patchin and Sameer Hinduja, "Bullies Move Beyond the Schoolyard: A Preliminary Look at Cyberbullying", Youth Violence and Juvenile Justice, 4, 148-169; Tracey E. Waasdorp and Catherine P. 
Bradshaw, "The Overlap between Cyberbullying and Traditional Bullying", Journal of Adolescent Health, 56, 483-488.

Note 24. See Aristotle, Nicomachean Ethics, trans. Terence Irwin, 2nd ed. (Indianapolis: Hackett Publishing Company, 1999). Also, for contemporary virtue ethics see, Alasdair MacIntyre, After Virtue: A Study in Moral Theory (Notre Dame, Ind. University of Notre Dame Press, 1984); Bernard Williams, Ethics and the Limits of Philosophy (Oxford: Routledge, 2006); G.E.M. Anscombe "Modern Moral Philosophy", Philosophy, 33(124), 1958.

See also, Immanuel Kant, "Foundations of the Metaphysics of Morals" (1775), in The Critique of Practical Reason and Other Writings in Moral Philosophy, trans. Lewis White Beck (Chicago: University of Chicago Press, 1949): 73-74, 80-83, 86-87.

Note 25. Aristotle. The Nicomachean Ethics in Introduction to Aristotle, 2nd ed, by Richard McKeon (Chicago: University of Chicago Press, 1973): 347.

Note 26. Ibid., 377-380.

Note 27. Jeremy Bentham, Principles of Morals and Legislation in The Works of Jeremy Bentham, ed. John Bowring, London, 1838-1843; Reprinted New York, 1962, Volume 1, Chapter 1.

Note 28. John Stuart Mill, Utilitarianism in Essential Works of John Stuart Mill, Ed. by Max Lerner (New York: Bantam Books, 1961): 194.

Note 29. Immanuel Kant, Grounding for the Metaphysics of Morals. Trans. by J. W. Ellington (Indianapolis: Hackett Publishing Company, 1993): 30.

Note 30. Ibid., 36.

Note 31. John Rawls, A Theory of Justice (Cambridge: Harvard University Press, 1999): 118.

Note 32. Curriculum development as an effective tool in the prevention of bullying is addressed by E. Marcoux in "Cyberbullying and Technology", Teacher Librarian, 42, 67-70 and by Dan Olweus, Susan Limber and Shatron F. Mihalic. Ibid. 1999a, 1000b.

Note 33. Carl Ballenas, e-mail correspondence, December 2, 2014. Mr. Ballenas is a sixth grade teacher at Immaculate Conception Middle School in Jamaica Estates, NY.

Note 34. Brighton Wood, St. John's University student.

Note 35. Andrew Harding, St. John's University student.

Note 36. Josephine Ferguson, Immaculate Conception Middle School student.

Note 37. Lobib Komal, Immaculate Conception Middle School student.

Note 38. Anthony Saginario, St. John's University student.

Note 39. Brismma Wright, Immaculate Conception Middle School student.

Note 40. Kelsey Lewis, Immaculate Conception Middle School student.

Note 41. Melvin Juwah, Immaculate Conception Middle School student.

Note 42. May A. Webber, "Bullying and Moral Responsibility". In S. Inal, \& M. A. Webber (Eds.), From Communication Landscapes to Bullying Battlegrounds (Oxford: UK, Inter-Disciplinary Press, 2014). https//:www.interdisciplinarypress.net/online-store/ebooks/ethos-and-modern-life/from-communication-landscap es-to-bullying-backgrounds. This paper contains the course's syllabus and provides a discussion of the rationale for its topics

Bullying and Moral Responsibility arose out of a call for the faculty of St. John's University's College of Professional Studies to develop new cutting edge courses incorporating an innovative use of technology. An ethics course on bullying is now an exciting addition to the College's philosophy curricula. 


\section{Appendix A}

Units of Instruction:

1) An historical perspective of bullying

2) The term bully: its etymology

3) Definitions: bullying and cyber- bullying

4) Species of bullying:

a. Physical

b. Non-physical: Verbal/non-verbal

5) Components

6) Bullying 21st century style: Cyber-bullying and the forms it can take

7) Descriptive ethics, normative ethics, and meta-ethics

8) Ethical relativism vs. ethical objectivism

9) Cultural relativism and ethical subjectivism

10) Teleological ethical theory:

a. Virtue ethics

b. Utilitarianism

11) Deontological ethical theory:

a. Kant's ethics of duty: Categorical imperative, practical imperative, criteria of reversibility

b. Rawls' contractarianism: Veil of ignorance

12) Application of ethical theory to bullying and cyber-bullying: Aristotle

13) Moral responsibilities imposed by the act of bullying

14) Bridging the gap between moral belief and action

15) Academic service-learning project: Collaboration between "philosophy" and "practicum" students in the development of an academic-service learning project (Note 42).

\section{Copyrights}

Copyright for this article is retained by the author(s), with first publication rights granted to the journal.

This is an open-access article distributed under the terms and conditions of the Creative Commons Attribution license (http://creativecommons.org/licenses/by/4.0/). 